\title{
A kézhigiénés technika vizsgálata elektronikus ellenőrző berendezés segítségével 26 magyarországi betegellátó intézményben
}

\author{
Lehotsky Ákos ${ }^{*}$. Morvai Júlia ${ }^{2,3 *}$ - Szilágyi László dr. ${ }^{4,5}$ \\ Bánsághi Száva ${ }^{1}$ - Benkó Alíz ${ }^{3}$. Haidegger Tamás dr. ${ }^{6,7}$ \\ Semmelweis Egyetem, Általános Orvostudományi Kar, ${ }^{1}$ Kísérletes és Sebészeti Mütéttani Intézet, \\ ${ }^{2}$ Patológiai Tudományok Doktori Iskola, Budapest \\ ${ }^{3}$ Hartmann-Rico Hungária Kft., Biatorbágy \\ ${ }^{4}$ Sapientia Egyetem, Marosvásárhelyi Kar, Marosvásárhely, Románia \\ ${ }^{5}$ Budapesti Múszaki és Gazdaságtudományi Egyetem, Irányítástechnika és Informatika Tanszék, Budapest \\ ${ }^{6}$ Austrian Center for Medical Innovation and Technology, Wiener Neustadt, Ausztria \\ ${ }^{7}$ Óbudai Egyetem, Bejczy Antal iRobottechnikai Központ, Budapest
}

Bevezetés: A helyes kézhigiéné jelentőségét nem lehet vitatni. Semmelweis óta tudjuk, hogy a kézhigiéné a kórházi fertőzések megelőzésének egyik leghatékonyabb módja, amelynek fejlesztésére az oktatás, az ellenőrzés és a visszacsatolás módszere javasolt.

Célkitüzés: A modern oktatási eszközök, digitális demonstráló és ellenőrző eszközök hatékonyságának felmérése a széles körü alkalmazásuk során.

Módszer: Az általunk szervezett kézhigiénés továbbképzéseken 1269 egészségügyi szakdolgozó vett részt, amelynek keretében a résztvevők kézhigiénés technikáját is vizsgáltuk, felmérve a kézhigiéné során leggyakrabban kimaradó területeket. A kézhigiénés technikát digitális berendezés segítségével vizsgáltuk.

Eredmények: A felmérésben részt vevők 33\%-a nem megfelelően fertőtlenítette a kezét. A leggyakrabban kihagyott területek az ujjvégek (bal kézen 33\%, jobb kézen 37\%) és a hüvelykujjak (bal kézen 42\%, jobb kézen 32\%) voltak.

Következtetés: A visszajelzésnek alapvető szerepe van a helyes kézhigiénés technika oktatásában és fejlesztésében, az elektronikus eszközök segítségével ez gyorsan és egyszerúen kivitelezhető, ezáltal pedig a képzés hatékonysága növelhető.

Orv Hetil. 2017; 158(29): 1143-1148.

Kulcsszavak: kézhigiéné, kézfertőtlenítés, compliance

\section{Hand hygiene technique assessment using electronic equipment in 26 Hungarian} healthcare institutes

Introduction: Hand hygiene is probably the most effective tool of nosocomial infection prevention, however, proper feedback and control is needed to develop the individual hand hygiene practice.

Aim: Assessing the efficiency of modern education tools, and digital demonstration and verification equipment during their wide-range deployment.

Method: 1269 healthcare workers took part in a training organized by our team. The training included the assessment of the participants' hand hygiene technique to identify the most often missed areas. The hand hygiene technique was examined by a digital device.

Results: 33\% of the participants disinfected their hands incorrectly. The most often missed sites are the fingertips (33\% on the left hand, $37 \%$ on the right hand) and the thumbs ( $42 \%$ on the left hand, $32 \%$ on the right hand). 
Conclusion: The feedback has a fundamental role in the development of the hand hygiene technique. With the usage of electronic devices feedback can be provided efficiently and simply.

Keywords: hand hygiene, hand disinfection, compliance

Lehotsky Á, Morvai J, Szilágyi L, Bánsághi Sz, Benkó A, Haidegger T. [Hand hygiene technique assessment using electronic equipment in 26 Hungarian healthcare institutions]. Orv Hetil. 2017; 158(29): 1143-1148.

(Beérkezett: 2017. április 21.; elfogadva: 2017. május 27.)

\section{Rövidítések}

$\mathrm{CI}=$ konfidenciaintervallum; EEKH: Egészségügyi Engedélyezési és Közigazgatási Hivatal; RFID = (radio frequency identification) rádiófrekvenciás azonosítás; UV = ultraibolya sugárzás; WHO = (World Health Organization $)$ Egészségügyi Világszervezet

Semmelweis Ignác (1818-1865) megfigyelése alapozta meg a kézhigiéné fejlődését. Munkássága nyomán nyilvánvalóvá vált, hogy a kézhigiéné a legfontosabb eleme a nosocomialis fertózések megelőzésének [1]. A kórházi fertőzések megelőzése az egészségügyi minőségbiztosítás és a betegbiztonság egyik pillére [2], amelynek nemcsak hatékony, hanem költséghatékony eszköze is a kézhigiéné [3]. A kórházi fertőzések 20-40\%-ában az egészségügyi személyzet keze játszik szerepet [4], amely a betegápolás során szennyeződik [5]. A kézhigiéné feladata a reziduális flóra csíraszámának a csökkentése, kivitelezésére pedig az alkoholos bedörzsölés javasolt, amennyiben a kézről a látható szennyeződést már eltávolították $[6,7]$.

A rendelkezésre álló megoldások közül, amelyek a kézhigiénés magatartást javíthatják $[8,9]$, a leghatékonyabbnak az automatizált, direkt ellenőrzés és a visszacsatolás bizonyult. A digitális eszközök egyre jobban beépülnek az életünkbe, az egészségügyben is egyre nagyobb szerephez jut az elektronika. A kézhigiéné területén az első generációs kísérleti ellenőrző rendszerek üzemelnek, így egy most induló globális folyamatnak lehetünk szemtanúi, amelynek révén pár éven belül a minőségbiztosítási rendszerek alapját képezhetik az elektronikus rendszerek [10-13].

\section{Módszer}

A Hartmann-Rico Hungária Kft. és HandInScan Zrt. közös szervezésében megtartott „Teljes körü kézhigiéniai oktatás és ellenőrzés" címú, EEHK 26904/2014 számon akkreditált képzésre 2015. június és 2016. szeptember között Magyarországon 26 betegellátó intézmény jelentkezett. A kórházi fertőzéseket és megelőzésük lehetséges módjait bemutató elméleti előadások mellett egy gyakorlati részt is beépítettünk a továbbképzésbe, amelynek keretében a résztvevők kézhigiénés technikáját digitális berendezéssel (Semmelweis Scanner, HandInScan Zrt., Magyarország) vizsgáltuk (1. ábra). A továbbképzésre jelentkezők tisztában voltak a képzés menetével, így a felmérésben való részvételük önkéntesnek tekinthetó (ráutaló magatartás). Ennek ellenére elófordult, hogy az elméleti oktatás után a szakdolgozó nem kívánt a gyakorlati felmérésen részt venni. Az ilyen esetek okát nem vizsgáltuk. A továbbképzés gyakorlati felméréséhez összesen 1269 egészségügyi szakdolgozó csatlakozott. A Semmelweis Scannert alkalmaztuk a kézhigiénés technika minősítésére, amely a beépített digitális képfeldolgozó algoritmusainak köszönhetően a képernyőn kirajzolja a kéz felszínén a megfelelóen és nem megfelelően fertőtlenített területeket $[14,15]$. A rendszer alapját a korábbi fluoreszcens technológia továbbfejlesztése jelentette oly módon, hogy számítógépes képfeldolgozást építettek a készülékbe. A fejlesztés célja, hogy humán erőforrás nélkül biztosítson visszajelzést, ezzel kizárva az emberi szubjektivitás lehetőségét. A digitális kamera a számítógépes kiértékeléshez UV-sugárzás által megvilágított környezetben képet készít az UVadalékkal kevert speciális fertőtlenítőszerrel bedörzsölt kézről, majd a számítógép vizuális és számszerú eredményt is ad a fertőtlenítés minőségéról.

A felmérés minden intézményben azonos módon történt. Az elméleti oktatás után a szakdolgozók következő adatait kérdő́ives módszerrel rögzítettük: nem, életkor (10 éves osztályközökkel), beosztás, egészségügyben el-

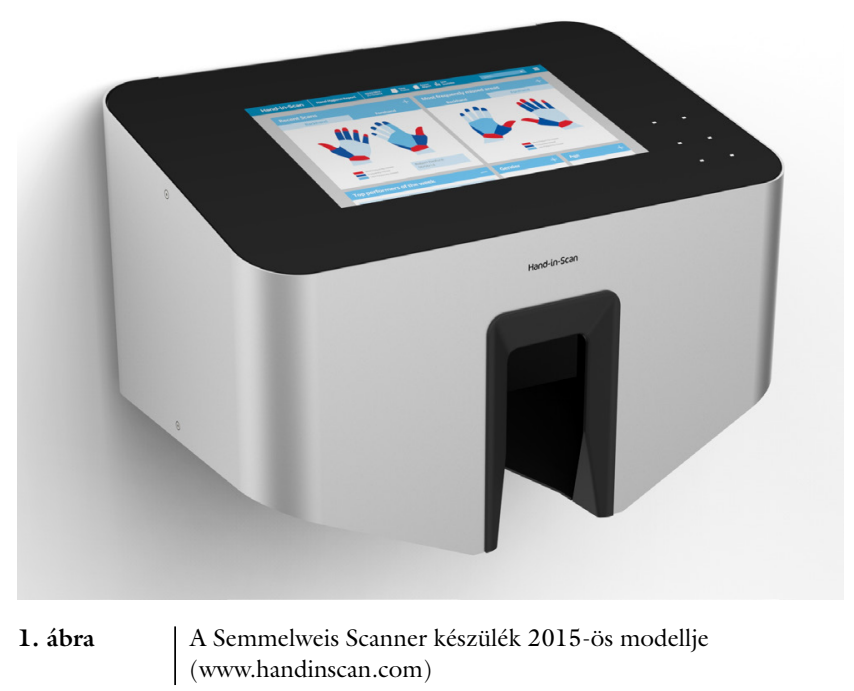


töltött idő, domináns kéz. A kérdőívet sorszámmal láttuk el. A következő lépésben a kézfertőtlenítés következett, amely során a kézfelszínre speciális, UV-markerrel kevert, oktatásra kifejlesztett fertőtlenítőszert juttattunk (Sterillium+Visirub, Hartmann GmbH, Németország). $\mathrm{Az}$ adagolt szer mennyiségét mindenki maga választhatta meg, a kihelyezett adagolóból adagolva a saját tenyerébe az általa megfelelőnek ítélt fertőtlenítőszer-mennyiséget. A felmérés utolsó lépéseként a felvitt fertőtlenítőszer eloszlását, tehát a bedörzsölés minőségét mutattuk meg az elektronikus berendezés segítségével. A Semmelweis
Scannert az oktatásban részt vevő szakember kezelte. Mindenki egyedi RFID-et (elektronikus azonosító kártya) kapott, amelynek sorszáma megegyezett a kérdőívének sorszámával. Az RFID-kártya segítségével indítható a mérés a készüléken, ennek sorszáma alapján köthettük össze a kérdőív adatait a mérés során kapott eredménynyel. A felmérésnél a szakdolgozó azonnali visszajelzést kapott a bedörzsölés minőségéről a berendezés képernyőjén megjelenő eredménykép segítségével.

A készülékkel UV-sugárzásban rögzített felvételeket ezután retrospektív módon értékeltük. A kéz felszínét

1. táblázat |A 2015. június és 2016. szeptember között folytatott kézhigiénés oktatásban részt vevő egészségügyi dolgozók adatai

\begin{tabular}{|c|c|c|c|c|c|c|c|c|c|c|c|c|}
\hline \multirow[t]{2}{*}{ Időpont } & \multicolumn{3}{|c|}{ Résztvevők } & \multicolumn{2}{|c|}{ Nem } & \multicolumn{5}{|c|}{ Korcsoport } & \multicolumn{2}{|c|}{ Domináns kéz } \\
\hline & $\begin{array}{l}\text { Összes } \\
\text { résztvevő }\end{array}$ & Hibázók & $\begin{array}{c}\text { Hibázók } \\
\text { aránya }\end{array}$ & Férfi & Nő & $<25$ & $26-35$ & $36-45$ & $46-55$ & $>56$ & Jobb & $\mathrm{Bal}$ \\
\hline 2015.06 .08 & 95 & 25 & $26 \%$ & 13 & 82 & 9 & 26 & 38 & 17 & 5 & 87 & 8 \\
\hline 2015.09 .24 & 47 & 15 & $32 \%$ & 6 & 41 & 3 & 4 & 17 & 18 & 5 & 42 & 5 \\
\hline 2015.10 .27 & 56 & 22 & $39 \%$ & 4 & 52 & 1 & 9 & 27 & 14 & 5 & 54 & 2 \\
\hline 2015.10 .29 & 85 & 23 & $27 \%$ & 5 & 80 & 3 & 13 & 27 & 28 & 14 & 83 & 2 \\
\hline 2015.11. 11 & 92 & 26 & $28 \%$ & 6 & 86 & 0 & 12 & 44 & 30 & 6 & 90 & 2 \\
\hline 2015.11 .24 & 43 & 15 & $35 \%$ & 1 & 42 & 1 & 5 & 22 & 11 & 4 & 40 & 3 \\
\hline 2016.01 .19 & 75 & 26 & $35 \%$ & 8 & 67 & 4 & 11 & 29 & 25 & 6 & 70 & 5 \\
\hline 2016.01 .20 & 88 & 58 & $66 \%$ & 5 & 83 & 12 & 12 & 36 & 16 & 9 & 81 & 7 \\
\hline 2016.02 .11 & 16 & 2 & $13 \%$ & 0 & 16 & 0 & 5 & 9 & 1 & 1 & 14 & 2 \\
\hline 2016.02 .11 & 17 & 6 & $35 \%$ & 2 & 15 & 0 & 3 & 5 & 8 & 1 & 15 & 2 \\
\hline 2016.03 .03 & 32 & 12 & $38 \%$ & 1 & 31 & 0 & 1 & 15 & 12 & 4 & 28 & 4 \\
\hline 2016.03 .04 & 28 & 8 & $29 \%$ & 0 & 28 & 3 & 2 & 11 & 11 & 1 & 27 & 1 \\
\hline 2016.03 .10 & 31 & 8 & $26 \%$ & 0 & 31 & 0 & 3 & 9 & 17 & 2 & 30 & 1 \\
\hline 2016.03 .22 & 15 & 7 & $47 \%$ & 0 & 15 & 2 & 1 & 3 & 6 & 3 & 14 & 1 \\
\hline 2016.03 .31 & 55 & 9 & $16 \%$ & 4 & 51 & 4 & 6 & 24 & 17 & 4 & 55 & 0 \\
\hline 2016.04 .06 & 77 & 26 & $34 \%$ & 6 & 71 & 16 & 14 & 30 & 16 & 1 & 67 & 10 \\
\hline 2016.04 .12 & 23 & 8 & $35 \%$ & 4 & 19 & 16 & 1 & 5 & 1 & 0 & 22 & 1 \\
\hline 2016.04 .12 & 18 & 5 & $28 \%$ & 0 & 18 & 4 & 3 & 4 & 6 & 1 & 17 & 1 \\
\hline 2016.04 .28 & 66 & 22 & $33 \%$ & 7 & 59 & 3 & 13 & 23 & 18 & 9 & 59 & 7 \\
\hline 2016.05 .12 & 29 & 10 & $34 \%$ & 8 & 21 & 2 & 8 & 7 & 9 & 3 & 29 & 0 \\
\hline 2016.05 .25 & 24 & 7 & $29 \%$ & 4 & 20 & 4 & 5 & 7 & 6 & 2 & 22 & 2 \\
\hline 2016.05 .04 & 43 & 10 & $23 \%$ & 1 & 42 & 2 & 6 & 16 & 15 & 4 & 41 & 2 \\
\hline 2016.05 .18 & 39 & 13 & $33 \%$ & 1 & 38 & 2 & 0 & 17 & 17 & 3 & 36 & 3 \\
\hline 2016.05 .30 & 50 & 16 & $32 \%$ & 2 & 48 & 3 & 3 & 13 & 24 & 7 & 45 & 5 \\
\hline 2016.06 .01 & 30 & 9 & $30 \%$ & 6 & 24 & 3 & 4 & 15 & 8 & 0 & 27 & 3 \\
\hline 2016.09 .06 & 38 & 10 & $26 \%$ & 13 & 25 & 0 & 4 & 15 & 13 & 6 & 37 & 1 \\
\hline 2016.09 .07 & 11 & 6 & $55 \%$ & 1 & 10 & 0 & 1 & 1 & 6 & 3 & 10 & 1 \\
\hline 2016.09 .06 & 13 & 4 & $31 \%$ & 0 & 13 & 1 & 1 & 5 & 4 & 2 & 13 & 0 \\
\hline 2016.09 .08 & 5 & 3 & $60 \%$ & 0 & 5 & 0 & 0 & 2 & 3 & 0 & 5 & 0 \\
\hline 2016.09 .14 & 28 & 6 & $21 \%$ & 1 & 27 & 1 & 1 & 10 & 12 & 4 & 26 & 2 \\
\hline Összesen & 1269 & 417 & $33 \%$ & 109 & 1160 & 99 & 177 & 486 & 389 & 115 & 1186 & 83 \\
\hline
\end{tabular}


régiókra osztottuk, mind a tenyér, mind a kézhát oldalán. A fertőtlenítésből kimaradó területeket a régiós felosztás szerint megszámoltuk, és elhelyezkedésük alapján összegeztük.

Az adatok statisztikai feldolgozására az R programcsomag 3.1.1.-es verzióját használtuk. A konfidenciaintervallumokat a PropCIs könyvtár segítségével határoztuk meg.

\section{Eredmények}

A felmérésben 26 egészségügyi intézmény 1269 egészségügyi dolgozója vett részt. A felmérés 2015 júniusától 2016 szeptemberéig zajlott, amely során 30 továbbképzési napot tartottunk. A résztvevők demográfiai adatait
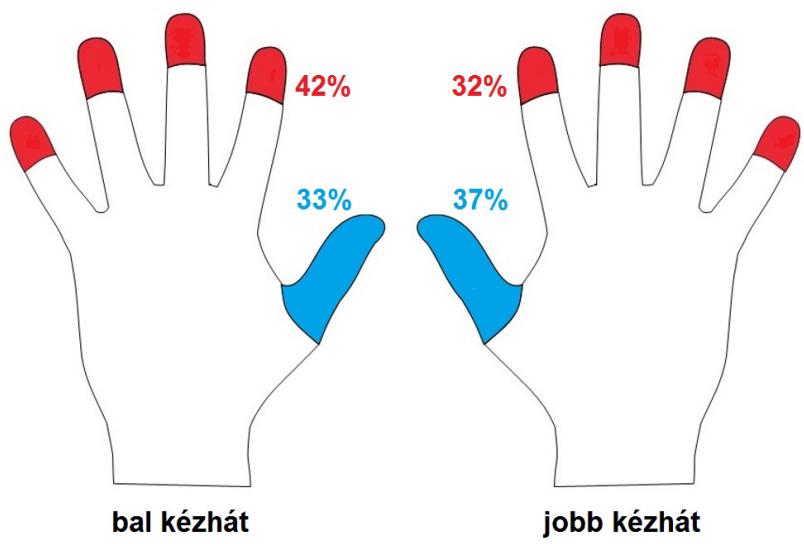

2. ábra $\mid$ Leggyakrabban kimaradó területek 1269 egészségügyi szakdolgozó kézfertőtlenítése során

\section{Az alkoholos kézbedörzsölés menete}

Kézhigiénéhez alkalmazzunk allkoholos bedörzsölést. Antibakteriális szappanos kézmosást akkor alkalmazzunk, ha a kezek láthatóan szennyezettek

(1) A múvelet időtartama: 30 másodperc

1 a

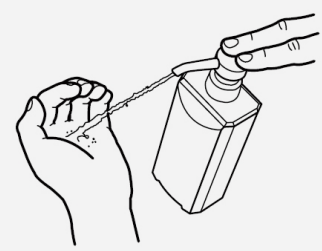

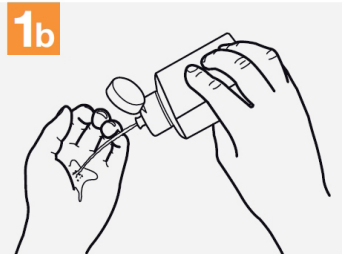

Adagolóból megfeleló mennyiségú kézfertőtlenító szert juttassunk a tenyérbe.

\section{3}

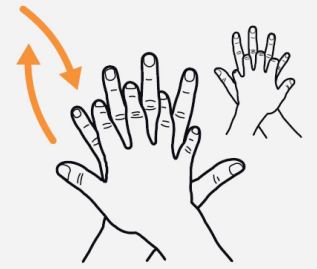

Dörzsöljük az egyik tenyerünkkel a másik kéz kézfejét úgy, hogy közben az ujjakat összefonjuk. Váltott kézzel ismételjük meg.

6

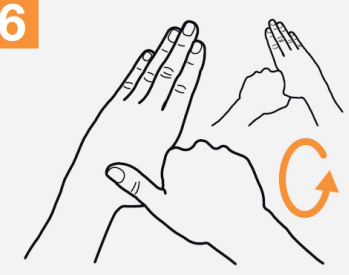

Markoljuk meg az egyik hüvelykujjat és körkörös mozdulattal dörzsöljük, majd váltsunk kezet.

\section{4}

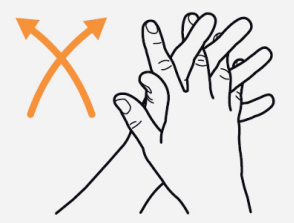

Dörzsöljük össze a két tenyeret úgy, hogy az ujjakat összefúzzük.

\section{7}

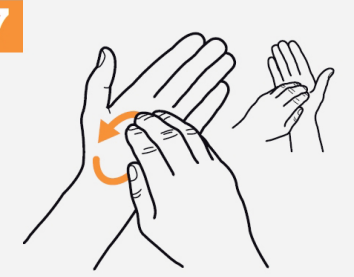

Az egyik kéz ujjbegyeit dörzsöljük a másik kéz tenyeréhez körkörösen, majd váltsunk kezet.

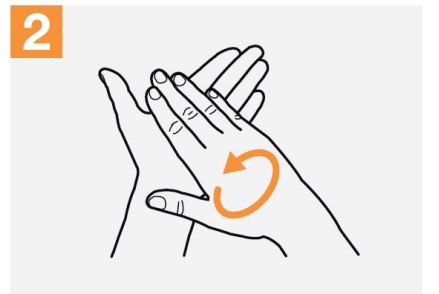

Dörzsöljük össze a tenyerünket.

5

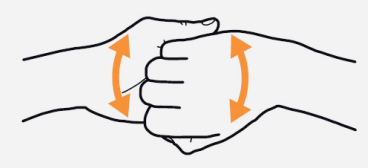

Dörzsöljük az egyik kéz tenyerével a másik kéz ujjainak hátát úgy, hogy az ujjak horogszerủen összeakaszkodnak. Váltott kézzel ismételjük meg.

8

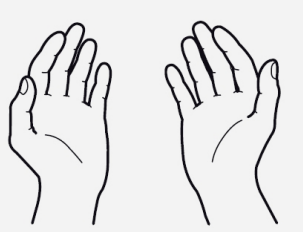

Száradás után kezeink biztonságosak. 
az 1. táblázatban foglaltuk össze. A résztvevők száma szerint a nők domináltak, mint általában a magyarországi egészségügyben. A vizsgált populáció $8 \%$-a volt 25 év alatti, a résztvevők legnagyobb része a 26-45 éves korcsoportba tartozott (52\%), csupán 9\%-uk volt 56 évesnél idősebb. A résztvevők 93,4\%-a jobbkezes, ami megegyezik a más intézményekben általában tapasztalt értékkel [16]. Összesen 417 résztvevőnél találtunk helytelenül fertőtlenített területeket, ami 33\%-os (95\%-os konfidenciaintervallum [CI]: 30-35\%) hibaarányt jelent.

A kézfelszínen megvizsgáltuk a fertőtlenítésből kimaradó területeket. A tenyéren összesen 12 nem megfelelően fertőtlenített területet találtunk, ez a mennyiség elhanyagolható a kézháton talált 1255 kimaradt területhez viszonyítva. A kézhát esetében mindkét kézen hasonló eredményt láthatunk: a leggyakrabban kimaradó területek az ujjvégek (jobb kézen az összes megszámolt sötét folt, vagyis nem fertőtlenített terület $37 \%$, bal kézen $42 \%$ ), majd a hüvelykujj (jobb kézen $37 \%$, bal kézen $33 \%)$. A kézháton leggyakrabban kimaradó területek eloszlását a 2. ábra mutatja be.

\section{Megbeszélés}

A helyes kézhigiéné kivitelezésére több nemzetközi irányelv ismert [17]. A leginkább elterjedt ezek közül a WHO által kidolgozott "hatlépéses protokoll”, amely során a fertőtlenítőszert a kézen hat különálló, egymást követő mozdulattal kell eloszlatni. A WHO hatlépéses protokolljának elemei: 1. tenyér-tenyér, 2. tenyér-kézhát, 3. ujjak között, 4. ujjak összefúzése, 5. hüvelykujj bedörzsölése, 6. ujjak vége (3. ábra).

A helytelenül kivitelezett mozdulatok a kéz felszínének hiányos bedörzsölését eredményezhetik. Egyes területek - például az ujjvégek és a hüvelykujj - könnyen kimaradhatnak a fertőtlenítésből, miközben ezek pont azok a területek, amelyeket a tárgyak megfogásához használunk [18].

A magas compliance-adatok csak a WHO „öt momentum” protokoll alapján elvárt kézhigiénés események nagyarányú végrehajtását jelentik, de a kézre juttatott fertőtlenítőszer eldörzsölésének minőségét nem jellemzik. A nem megfelelően kivitelezett kézfertőtlenítés során a kézen területek kimaradhatnak. A compliance növelése önmagában nem elég a fertőzések visszaszorítására, a kézfertőtlenítés eredményességét is vizsgálni kell, hogy biztosítsuk a betegek maximális védelmét.

A WHO protokollja alapján a legutolsó lépésben történik az ujjvégek bedörzsölése (hatodik lépés). A kapott eredmények (2. ábra) alapján valószínűsíthető, hogy ez a lépés nem tölti be a funkcióját. Ez lehet a helytelen kivitelezés következménye, azzal kiegészítve, hogy a fertőtlenítőszer párolgása miatt az utolsó lépésre már nem marad elegendő mennyiségű fertőtlenítőszer a kéz felületén.

\section{Következtetés}

A hagyományos infekciókontroll-oktatások legtöbbször csak elméleti alapot nyújtanak a dolgozóknak a megfelelő kézhigiénéről, de nem változtatják meg az évek alatt (esetleg hibásan) kialakult és berögzült szokásokat, mozdulatokat. A fertőtlenítőszer eloszlása szabad szemmel nem látható, de a modern eszközök segítségével a dolgozók szembesíthetők a saját eredményükkel, vizualizálva a kézen a kimaradó, nem fertőtlenített területeket. A számítógépes képfeldolgozás által adott kiértékelésnél a résztvevő az emberi tényező kizárásával kaphat minősítést az elvégzett feladatról. Az azonnali visszajelzés módszerét alkalmaztuk a megfelelő kézhigiénés technika tanításához, mert a valós idejü visszajelzés a leghatékonyabb eszköz a viselkedésformáláshoz. Miután a résztvevők személyre szabott visszajelzést kaptak egyéni kézhigiénés teljesítményükrôl, lehetőségük nyílt technikájuk javítására.

Anyagi támogatás: A közlemény megírása anyagi támogatásban nem részesült.

Szerzői munkamegosztás: L. Á.: Adatgyưjtés, irodalomkutatás, publikáció megírása. M. J.: Adatgyưjjtés, publikáció megírása. B. Sz.: Irodalomkutatás, a publikáció szerkesztése. Sz. L.: Adatok elemzése. H. T.: Szakmai vezetés.

Érdekeltségek: L. Á., H. T. és Sz. L. a HandInScan Zrt. társalapítói.

\section{Köszönetnyilvánítás}

A szerzők köszönetet mondanak a Hartmann-Rico Hungária Kft. vezetőinek és dolgozóinak a felmérés támogatásáért.

\section{Irodalom}

[1] Pittet D, Boyce JM. Hand hygiene and patient care: pursuing the Semmelweis legacy. Lancet Infect Dis. 2001; 1(Suppl 1): 9-20.

[2] Steed C, Kelly JW, Blackhurst D, et al. Hospital hand hygiene opportunities: Where and when (HOW2)? The HOW2 Benchmark Study. Am J Infect Control 2011; 39: 19-26.

[3] Boyce JM, Pittet D. Guideline for hand hygiene in health-care settings - Recommendations of the Healthcare Infection Control Practices Advisory Committee and the HICPAC/SHEA/ APIC/IDSA Hand Hygiene Task Force. Am J Infect Control 2002; 30: S1-S46.

[4] Weber DJ, Rutala WA, Miller MB, et al. Role of hospital surfaces in the transmission of emerging health care-associated pathogens: Norovirus, Clostridium difficile, and Acinetobacter species. Am J Infect Control. 2010; 38: S25-S33.

[5] Pittet D, Dharan S, Touveneau S, et al. Bacterial contamination of the hands of hospital staff during routine patient care. Arch Intern Med. 1999; 159: 821-826.

[6] WHO guidelines on hand hygiene in health care. World Health Organization, 2009; pp. 123-136. 
[7] Milassin M, Pechó Z, Böröcz K, et al. Technical letter: The practice of hand hygiene in the healthcare and nursing services. [Módszertani levél. A kézhigiéne gyakorlata az egészségügyi és az ápolást végző szociális szolgáltatásokban.] Epinfo 2010; 17: 3-27. [Hungarian]

[8] Mayer J, Mooney B, Gundlapalli A, et al. Dissemination and sustainability of a hospital-wide hand hygiene program emphasizing positive reinforcement. Infect Control Hosp Epidemiol. 2011; 32: 59-66.

[9] Boyce M. Measuring healthcare worker hand hygiene activity: current practices and emerging technologies. Infect Control Hosp Epidemiol. 2011; 32: 1016-1028.

[10] Al-Tawfiq JA, Pittet D. Improving hand hygiene compliance in healthcare settings using behavior change theories: reflections. Teach Learn Med. 2011; 25: 374-382.

[11] Ward MA, Schweizer ML, Polgreen PM, et al. Automated and electronically assisted hand hygiene monitoring systems: A systematic review. Am J Infect Control 2014; 42: 472-478.

[12] Pineles LL, Morgan DJ, Limper HM, et al. Accuracy of a radiofrequency identification (RFID) badge system to monitor hand hygiene behavior during routine clinical activities. Am J Infect Control 2014; 42: 144-147.

[13] Marra AR, Edmond MB. New technologies to monitor healthcare worker hand hygiene. Clin Microbiol Infect. 2014; 20: $29-33$.
[14] Lehotsky Á, Szilágyi L, Ferenci T, et al. Quantitative impact of direct, personal feedback on hand hygiene technique. J Hosp Infect. 2015; 91: 81-84.

[15] Haidegger T, Nagy M, Lehotsky Á, et al. Digital imaging for the education of proper surgical hand disinfection. Lect Notes Comp Sci. 2011; 6893: 619-626.

[16] Hardyck C, Petrinovich LF. Left-handedness. Psychol Bull. 1977; 84: 385-404

[17] Reilly JS, Price L, Lang S, et al. A pragmatic randomized controlled trial of 6-step vs 3-step hand hygiene technique in acute hospital care in United Kingdom. Infect Control Hosp Epidemiol. 2016; 37: 661-666.

[18] Chen LF, Carriker C, Staheli R, et al. Observing and improving hand hygiene compliance: implementation and refinement of an electronic-assisted direct-observer hand hygiene audit program. Infect Control Hosp Epidemiol. 2013; 34: 207-210.

(Szilágyi László dr., Şos. Sighişoarei 1/C, 540485 Tîrgu Mureş, Románia

\section{e-mail: lalo@ms.sapientia.ro)}

\section{NOTA}

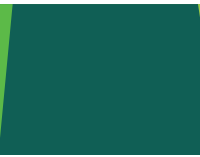

\section{Új fejlesztés az egészségügyben dolgozók, tanulók részére!}

\section{A magyar nyelvứ szakirodalmi keresőszolgáltatás}

\section{Mi a NOTA? \\ Napivizit Orvosi Tudástár Alkalmazás}

\section{Mit tud a NOTA portál?}

Megkönnyíti a magyar nyelvü szakirodalmi források keresését.

Eszköztöl függetlenül, akár okostelefonról, a betegágy mellett állva is használható.

\section{Miben kereshet a NOTA-val?}

Az Akadémiai Kiadó folyóirataiban: Orvosi Hetilap, Magyar Sebészet, Mentálhigiéné és Pszichoszomatika.

Más kiadók magyar nyelvú szakfolyóirataiban: pl. Lege Artis Medicinae, Hypertonia és Nephrologia, Ideggyógyászati Szemle.

A hatályos szakmai irányelvekben.

Magyar nyelvủ kérdésekre adott angol nyelvű találatokban, a PubMeden.

\section{nota.hu}

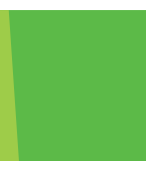

\section{Akadémiai Kiadó}

A Wolters Kluwer Csoport tagja

1117 Budapest, Prielle Kornélia u. 21-35. / Telefon: (1) 464-8246 www.akademiai.hu / www.akademiai.com

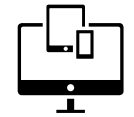

MNOTA

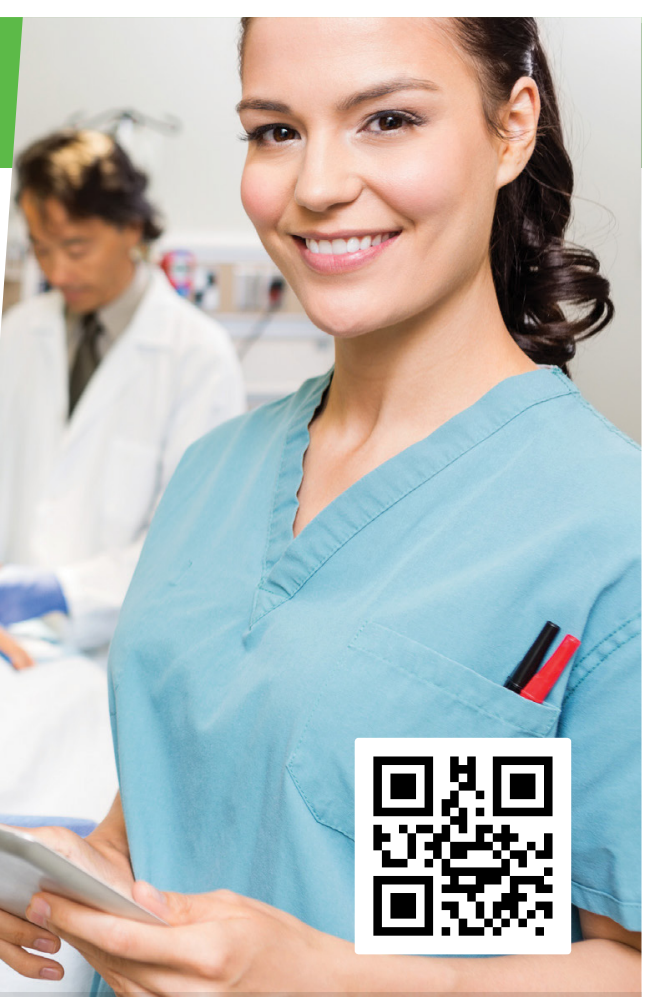

